\title{
Enclosure and Facade Fires: Physics and Applications
}

\author{
MICHAEL DELICHATSIOS, Director FireSERT \\ University of Ulster, Shore Road, Newtownabbey, BT37 0QB, UK
}

\begin{abstract}
Facade fires being a disastrous hazard for high rise building, as several historical and recent incidents have shown, have attracted the interests of numerous fire scientists, engineers and regulators. This work has as an objective to present issues in this area that are challenging and need further attention. It focuses on characterizing the flame height and heat fluxes from facade flames produced from under-ventilated enclosure fires on a facade that is not flammable. Such an investigation is an important consideration for practical applications as well as a prerequisite for examining fire spread on flammable facades and for designing a test for modern facade assemblies. The mass pyrolysis rates and burning of real fuels are discussed in under ventilated enclosures, rectangular or corridor like, for various openings presenting the current state and some critical issues. Facade flames are analyzed from experiments using gaseous burners to have control on the fuel supply rate by introducing physical length scales for the opening geometries to model flame heights and heat fluxes. An important parameter for the facade flames is the excess heat release rate of the fuel burning outside the enclosure. Finally, applications for facade flames with sidewalls and facade flames from two openings are presented.
\end{abstract}

KEYWORDS: enclosure fires, facade flames, excess heat release rates, flame heights, heat fluxes

\section{INTRODUCTION}

It is a difficult task to provide due credit to previous work related to enclosure and facade fires. Almost all fire scientists and engineers have had an input in this area. For this reason, I have put two lists of references one that is probably exhaustive (Appendix A) and the other that is related directly to this paper. The latter list is dominated by work done by my group and collaborators in Japan (TUS, Professor Y Ohmiya) and in China (SKLFS, Professor Longhua Hu).

I also point out that I will not include a discussion and relation of the present work with spill plumes where a great difference is that the boundary conditions for the facade flows and flames are better defined especially if mainly under ventilated fires are considered as done here.

It is widely recognized that facade flames and fire spread (see Fig. 1) can create serious hazard in high rise buildings owing to three mechanisms of fire spread:

- Flames ejecting form a window can break the window above allowing ignition in the next floor (leap-frogging)

- Failure of fire stopping between the floor slab and the exterior wall, and

- Heat flux impacts on the internal facade assembly (melting of metals, fire spread within insulation) allowing flames through

In order to design for mitigation of the facade fire spread hazard, one should be able to determine the size of the fire in the enclosure, the ejected facade flame properties (flame height and heat fluxes) and their impact on facade assemblies and building materials. The present paper addresses the enclosure fire and facade flames on an inert wall which are required to a) assess the impact, as for example, on fire resistance and flame spread on possibly flammable facade assemblies and b) provide inputs for the design of a reasonable facade test.

Figure 1 provides also an illustration of the contents of the present paper that consist of the next section on enclosure fires followed by a section on facade flames and then a section on applications of the methodologies, before we present conclusions and remaining challenges for fire safety engineering. In Fig. 1 the extent of continuous and intermittent flame ejected from an enclosure fire is indicated where $0.4 \mathrm{H}$ is the neutral plane. 


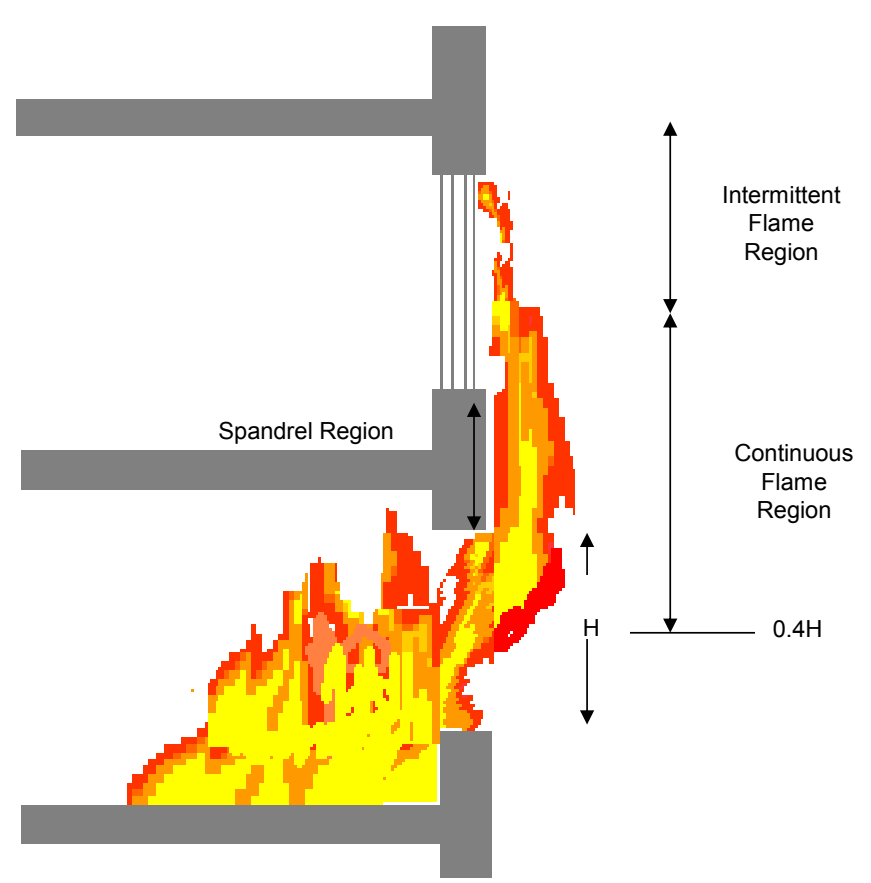

Fig. 1. Enclosure fire and floor to floor external fire spread.

\section{ENCLOSURE FIRES}

\section{Mass Pyrolysis Rate}

The main thrust of this section is a discussion of the mass pyrolysis rate inside an enclosure having an opening (Fig. 1) as the conditions change from over ventilated (fuel controlled) to under ventilated (oxidizer flow) controlled. For the present purpose, we exclude other interesting phenomena inside the enclosure such as ghost flames, burning oscillations, extinction and re-ignition.

The basic behavior of the mass pyrolysis rate in an enclosure is shown in the sketch of Fig. 2 and in the corresponding data in Fig. 3 [1] for enclosure fires. Both figures show that as ventilation rate (proportional to $A \sqrt{ } H)$ decreases the mass pyrolysis rate per unit fuel area $\left(\mathrm{A}_{\mathrm{F}}\right)$ first increases owing to radiation augmentation by the hot gases reaching a maximum and then becomes proportional to the ventilation rate $A \sqrt{ } H$ for under ventilated conditions. A significant observation is that the slope of the straight line on the left hand side in Fig. 2 is nearly 0.1, as Kawagoe [2] first found, independent of the fuel type (e.g. its heat of pyrolysis) or the enclosure geometry as long as combustion inside the enclosure can be sustained.

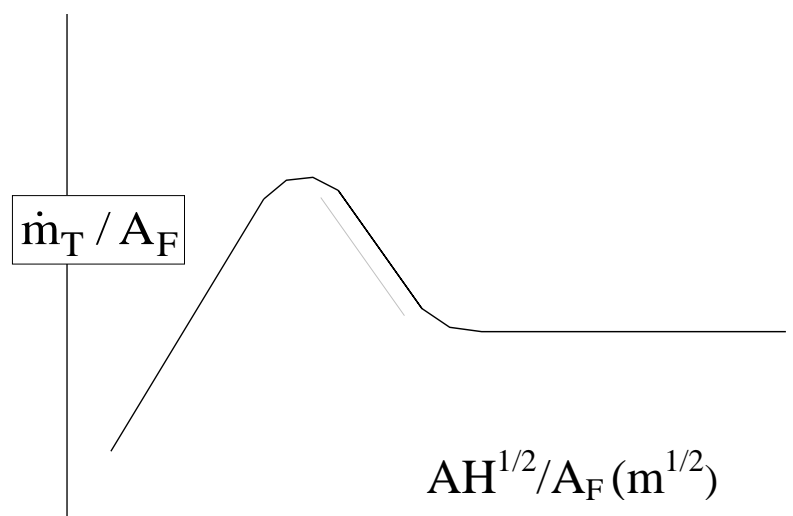

Fig. 2. Mass pyrolysis rate in an enclosure as the ventilation rate varies, both expressed per unit fuel area. 
Some recent modeling (Daisuke et al. [3]) of enclosure fires claims to support this result but the physics of why is this so are not clear. We will come to this matter later but this is clearly is a challenge for fire research. In addition, the maximum of the pyrolysis rate in Fig. 3 is reached at stoichiometric conditions as Fig. 4 implies because the abscissa is the air inflow for stoichiometric combustion where $S$ is the air to fuel equivalence ratio. We may summarize this section by providing the mass pyrolysis rate for under ventilated conditions as:

$$
\dot{\mathrm{m}}_{\mathrm{T}}=0.1 \mathrm{~A} \sqrt{\mathrm{H}}(\mathrm{kg} / \mathrm{s}) \text { in rectangular enclosures }
$$

Here the area $\mathrm{A}$ of the opening is in square meters and the height $\mathrm{H}$ of the opening in meters.

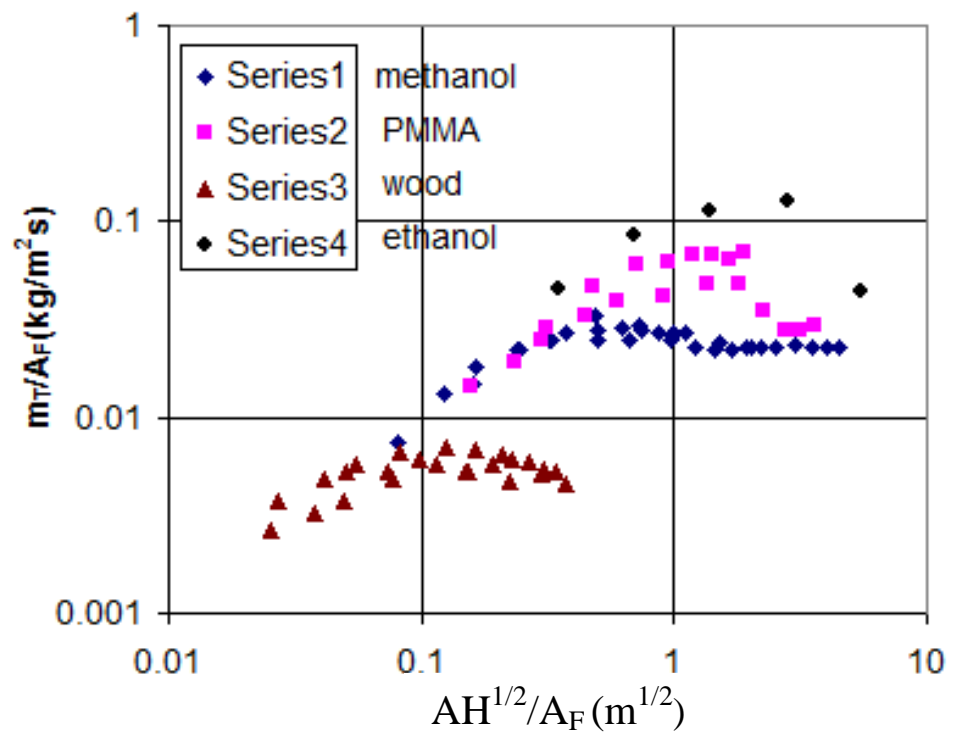

Fig. 3. Experimental data for mass pyrolysis and ventilation in an enclosure for different fuels expressed per unit surface area of the fuel $A_{F}$.

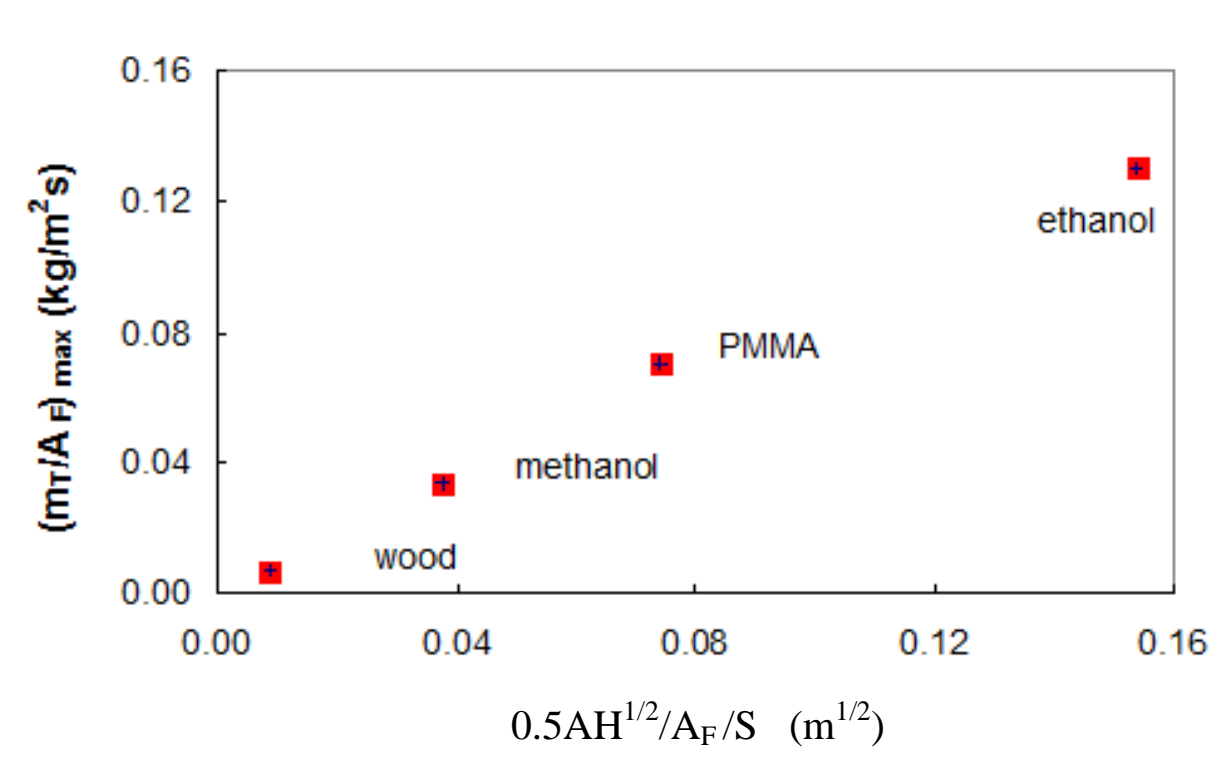

Fig. 4. Maximum pyrolysis rate from Fig. 3 is nearly equal to the stoichiometric requirements for the ventilation rate. The maximum pyrolysis rate is independent of the radiation properties of the fuel which will affect how fast this value is reached from its value at ambient burning. 
There is another remarkable discovery related to the mass pyrolysis rate in long corridors (see Fig. 6) as deduced from Fig. 5 for liquid pools [1], namely the mass pyrolysis rate is one quarter of the mass pyrolysis rate in rectangular openings where Eq. 1 applies:

$$
\dot{m}_{T}=0.025\left(2 A H^{1 / 2}\right) \text { in corridors }
$$

The factor of 2 accounts for the entrainment from both ends of the corridor. This ( slope 0.025 compared to $0.1)$ is another challenge we and other people try to address.

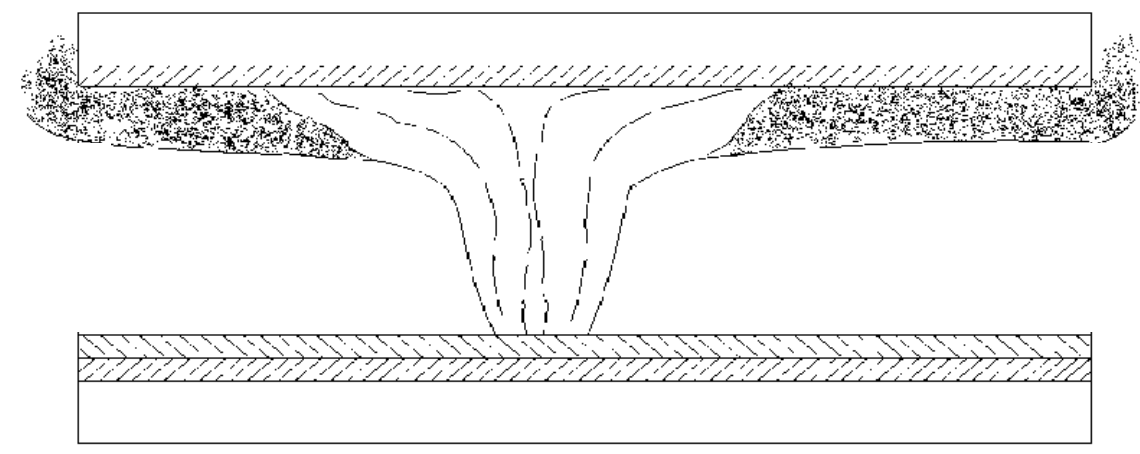

Fig. 5. Flow in a long corridor from a pool fire open at both ends.

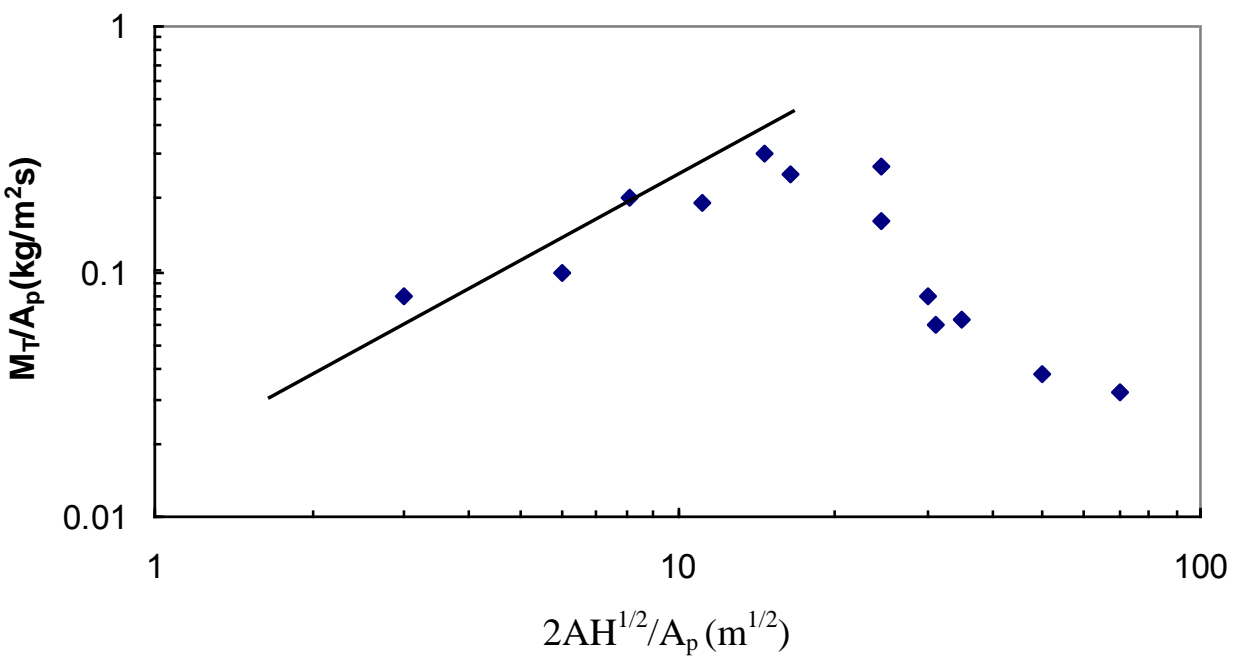

Fig. 6. Correlation of mass pyrolysis rate with the ventilation factor (mass rate of the air inflow) in fully involved corridor fires from under ventilated to over ventilated conditions. $A_{p}$ here is the same as $A_{F}$ namely the fuel surface area.

We will not discuss here over ventilated fires where an important consideration is the calculation of the heat fluxes to the fuel which consist of radiation from the hot layer, convection and radiation from the flames (e.g. ref [3 - 5]). A simplified methodology based on experiments to estimate these heat fluxes is given by Tofilo et al. [6] also important for the heating and possible breakup of glazing.

\section{Heat Release Rate inside the Enclosure for Under-ventilated Conditions}

To address the case of facade flames, one has to be able to calculate the fuel burning outside an enclosure for under ventilated fires which present the major hazard for external fire spread in high rise buildings. First we notice that for under ventilated fires [e.g. 7 -9] the gas temperatures inside the enclosure away from the opening are nearly uniform. In this case, it has been shown [1,10] that the air inflow is given by the expression

$$
\dot{m}_{a}=0.50 A \sqrt{H}(\mathrm{~kg} / \mathrm{s})
$$


The limitations of this equation have been examined in detail in the Appendix of reference [1] showing a small correction as $\dot{m}_{a}=0.50 A_{o} \sqrt{H_{o}}-\frac{1}{2} \dot{m}_{T}$ and a range of applicability for enclosure gas temperatures between 900 to $1200 \mathrm{~K}$. The gas temperatures (not explicitly presented here) inside the enclosure depend on the heat released inside the enclosure, the heat losses to the walls, and the convective and radiative heat losses through the opening [6,9]. In the following presentation we will use Eq. 3 because it is applicable for the scenarios analyzed.

Subsequent to Eq. 1 it was proposed by several authors $[4,5]$ that the heat released inside the enclosure is just the heat released by the complete consumption of the oxygen of the incoming air which can be calculated by multiplying the mass air inflow by $3000 \mathrm{~kJ} / \mathrm{kg}$, the heat released by the oxygen in air:

$$
\dot{Q}_{\text {inside }}=3000 \times 0.50 A \sqrt{H}=1500 A \sqrt{H}(\mathrm{~kW})
$$

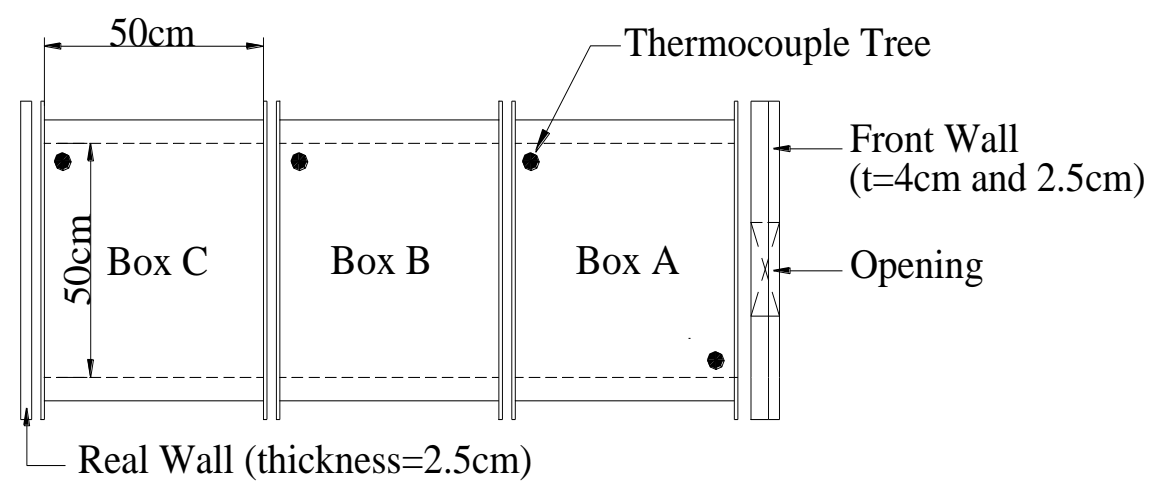

Fig. 7. Modular (box) enclosures used for the facade experiments [6] with a gaseous burner fuel source located at different boxes.

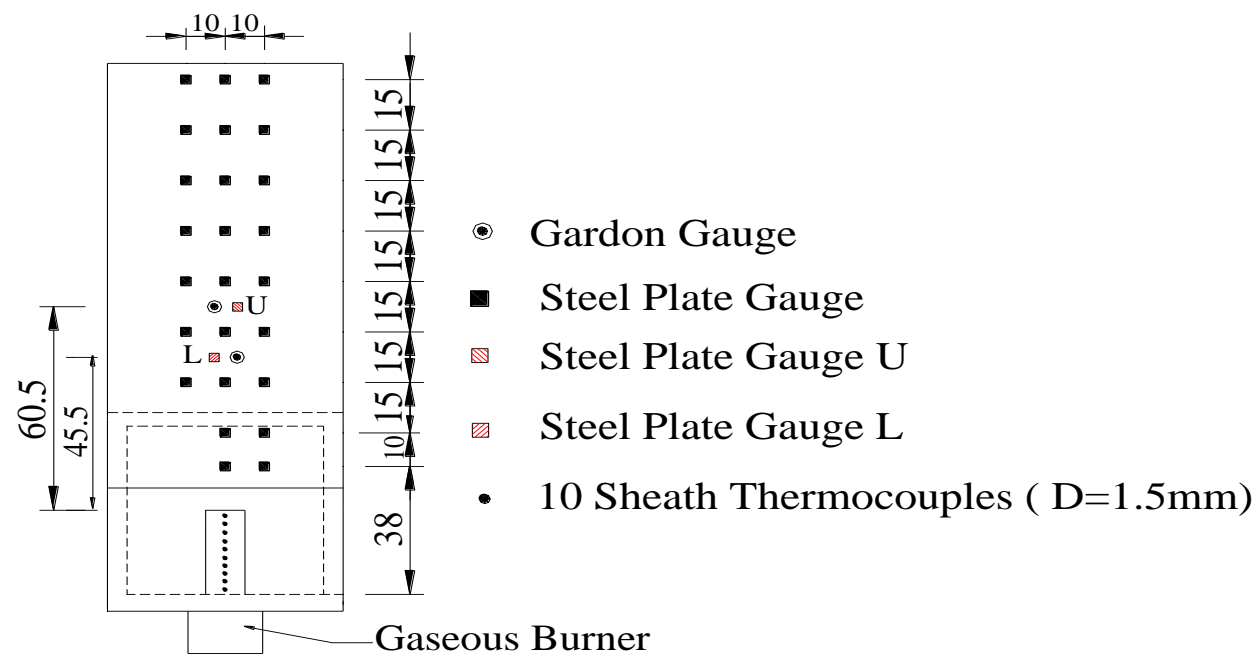

Fig. 8. The facade arrangement with an opening in the front and the instrumentation used in front of the modular enclosure in Fig. 7 [6]

It was shown definitely that this relation is valid in all the experiments by Lee et al. [7, 9] in enclosures using a gaseous burner and a facade well instrumented as shown in Figs 7 and 8. A typical plot of the heat release rate (HRR) measured in a collecting hood is shown in Fig. 9 together with the theoretical HRR of the supplied fuel (straight line) increasing linearly with time from 0 to $50 \mathrm{~kW}$. This figure 9 shows $[7,9]$ that as the conditions inside the enclosure become under ventilated (in about 8 minutes) and before external 
burning occurs (at about 13 minute) the HRR inside the enclosure remains constant and is given by Eq. 4 . One can also conclude from these experiments that the same energy is released inside the enclosure even after external burning occurs (at about 13 minutes) because the gas temperatures inside the enclosure [7,9] do not change after under ventilated conditions establish (in about 8 minutes).

We can now determine the "excess" heat released outside the enclosure as the heat from the complete burning of the fuel minus the heat released inside the enclosure:

$$
\dot{Q}_{\text {exc }}=\dot{m}_{T} \Delta H_{c}-1500 A \sqrt{H}(\mathrm{~kW})
$$

Here $\Delta \mathrm{H}_{\mathrm{c}}$ is the heat of combustion of the pyrolysing material or the gaseous fuel when a gas burner is the source fire. For a pyrolysing material, Eq. 5 together with Eq. 1 provides the following excess HRR;

$$
\dot{Q}_{e x c}=0.5 \Delta H_{c}(0.2-1 / S) A \sqrt{H}(\mathrm{~kW})
$$

Here we have used also the relation between the air to fuel stoichiometric ratio $\mathrm{S}$ and the heats of combustion ( $S=\Delta H_{c} / 3000$ ). This is another challenge because it proclaims that there cannot be excess HRR and excess pyrolysate $\left(\dot{Q}_{e x c} / \Delta H_{c}\right.$ ) if the stoichiometric ratio $S<5$ !. Having established the relation for the excess HRR, we continue in the next section with the examination of facade flames from enclosures for a gaseous burner fire source where the fuel supply is controlled so that Eq. 5 definitely applies.

\section{FACADE FLAMES}

Facade Flames from Under-ventilated Enclosure Fires Under-ventilated conditions exist when the heat release rate from the fuel is larger than $1500 A \sqrt{H}(\mathrm{~kW})$ as deduced from Eq. 5 and Fig. 9 and also being consistent with the results in Figs. 3 and 4 [7,8,9]. In this case flames will be established outside the enclosure as Fig. 9 also indicates after ignition of the excess pyrolysate occurs at the opening. Until ignition of the external flames occurs the HRR is constant $(16.8 \mathrm{~kW})$ as soon as under-ventilated conditions are created inside the enclosure. External burning can also occur at over-ventilated conditions simply when the flames from the source fire are long enough to extend beyond the opening. This situation has been several times confused in the literature to imply under-ventilated fire conditions inside the enclosure.

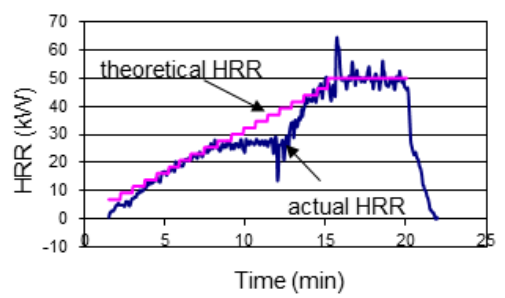

Fig. 9. Theoretical and measured heat release rate history for an experiment having $20 \mathrm{~cm}$ by $20 \mathrm{~cm}$ opening. The intermediate plateau indicates the heat released inside the enclosure is equal to

$$
1500 A \sqrt{H}=26.8 \mathrm{~kW} \text {. }
$$

Turning now to facade flames, we inevitably stumble over the widely used Yokoi method [4, 10] for correlating the gas temperatures of the facade flames. Before we discuss why the Yokoi method should be replaced we note that using the excess pyrolysate (Eq. 5) we were able [7 - 9] to correlate flame heights and heat fluxes to the facade wall using length scales associated with the flow at the exit of the enclosure. 
The appropriate length scales derived in Appendices B (where also the Yokoi method is outlined) and C are briefly explained next. The three length scales are

$$
\begin{aligned}
& \ell_{1}=(A \sqrt{H})^{2 / 5} \\
& \ell_{2}=\left(A H^{2}\right)^{1 / 4} \\
& \ell_{3} \propto\left(A H^{4 / 3}\right)^{3 / 10}
\end{aligned}
$$

The first length scale is related to the size of the opening required to accommodate the convective flow and the other two length scales are expressing the horizontal extension of the flow with or without flames outside the enclosure owing to the competition of horizontal momentum with the buoyancy. We note that the ratio of these two length scales,$\ell_{2} / \ell_{3} \propto(H / W)^{1 / 20}$, varies weakly with the aspect ratio (H/W, height over width) of the window so that $\ell_{2}$ can be retained for correlating the facade flame properties.

Figure 10 shows for example a correlation of the flame height using the length scale $\ell_{1}$ and the nondimensional excess HRR;

$$
\dot{\mathrm{Q}}_{\mathrm{ex}}^{*}=\frac{\dot{\mathrm{Q}}}{\rho_{\infty} \mathrm{C}_{\mathrm{p}} \mathrm{T}_{\infty} \sqrt{\mathrm{g} \ell_{1}^{5 / 2}}}
$$

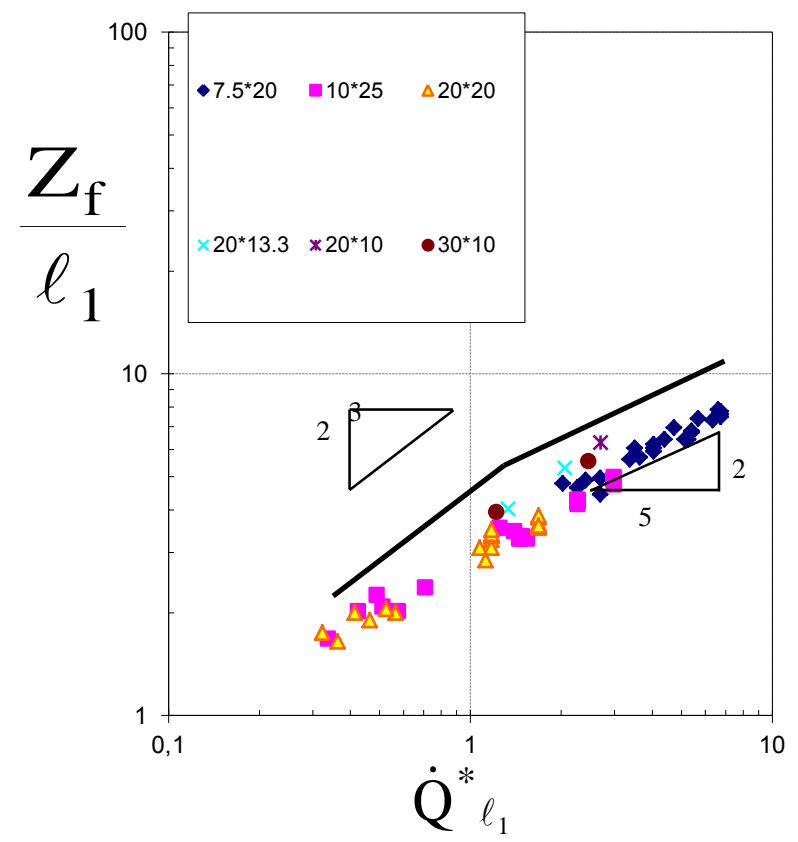

Fig. 10. Flame height correlation using the length scale $\ell_{1}$ (Eq. 7a) and the normalized excess HRR (Eq. 8)

A useful interpretation of this figure is that for $\dot{Q}_{e x}^{*}<1.3$ (slope of log-log line 2/3) the flames are two dimensional (like a line plume) and then for $\dot{Q}_{e x}^{*}>1.3$ (slope of log-log line 2/5) the flames become three dimensional. The heat flux measurements, see Fig. 11, are also correlated using the same length scales in [7] and in [9] where the heat fluxes on an opposed facade wall are measured and predicted. Heat flux 
measurements and correlations are essential for the safe design of facade walls. One additional point to make is that the radiation from the facade flames does not depend on the type of fuel in the enclosure because the fuel is preheated to about $800{ }^{\circ} \mathrm{C}$ before exiting the enclosure thus always producing a lot of soot.

$$
\frac{\dot{\mathrm{q}}_{\mathrm{t}}^{\prime \prime} \mathrm{Z}_{\mathrm{f}} \mathrm{e}^{0.6\left(\mathrm{H} / \ell_{1}\right)}}{\dot{\mathrm{Q}}_{\mathrm{ext}} / \ell_{1}}
$$

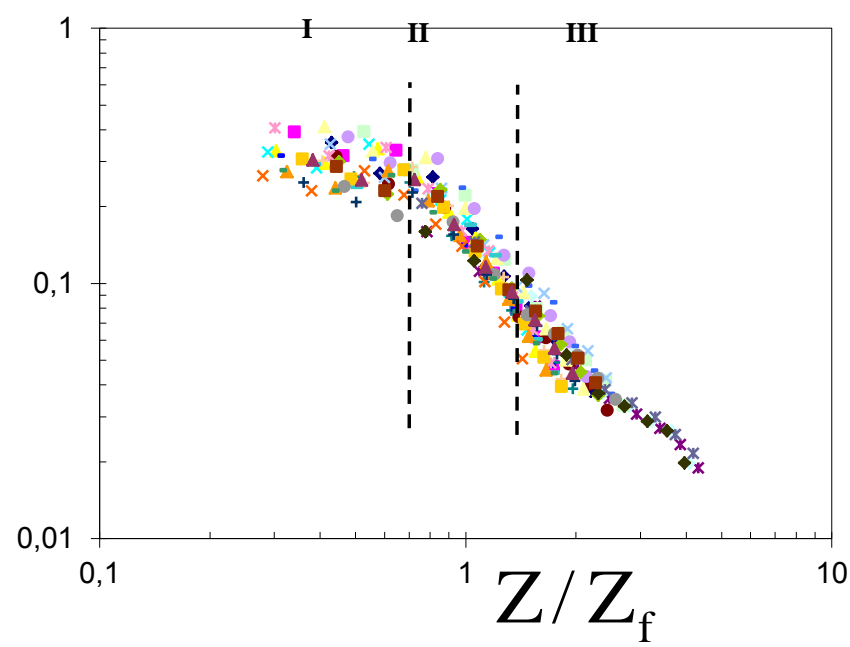

Fig. 11. Heat flux correlation at the center of the facade for all of enclosure geometries and all openings

Sometime after the development of the new length scales [7,9] we were able to publish [11] a detailed explanation why the Yokoi correlation [10] needs to be replaced. Two modifications were imposed on Yokoi's correlation on the gas temperatures on the facade flow, one replaces his length scale $r_{0}(\propto \sqrt{H W})$ by the new length scale $\ell_{1}$ and the other replaces the local density in the dimensionless temperature by the ambient density. These modifications were justified by analysis and verified (in Figs. 5 and 6 of reference 11) by comparison with Yokoi's experiments of the temperature variation on facades produced from enclosure fires. To my surprise, I discovered, while writing this paper, that Phil Thomas expressed great doubts regarding the Yokoi correlation [12] which are difficult to understand and I have to decided to include them as an Appendix $\mathrm{C}$ for the reader.

\section{APPLICATIONS TO OTHER FAÇADE FLAME CONFIGURATIONS}

Several applications [12 - 15] of the present results and methodologies have been made in collaboration with the Dr. Longhua Hu team in SKLFS (USTC) and with the Professor Yoshi Ohmiya team at TUS. As an example, we present two new correlations in Figs. 12 and 13 for the flame heights in the case of facade flames with sidewalls and in the case of facade flames from two windows of equal size on the facade wall. These four figures are taken from papers submitted for publication to International Heat and Mass Transfer Journal (sidewalls) and to the Combustion Institute 2014 (two windows). 


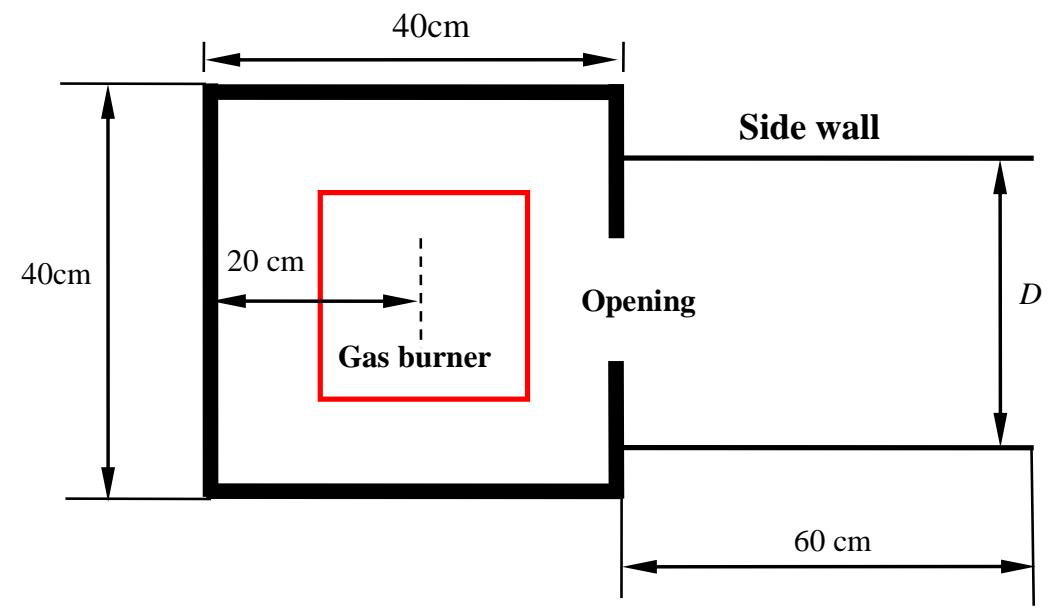

Fig. 12a. Top view of a facade flame experiment for an enclosure with two sidewalls located symmetrically to the opening.

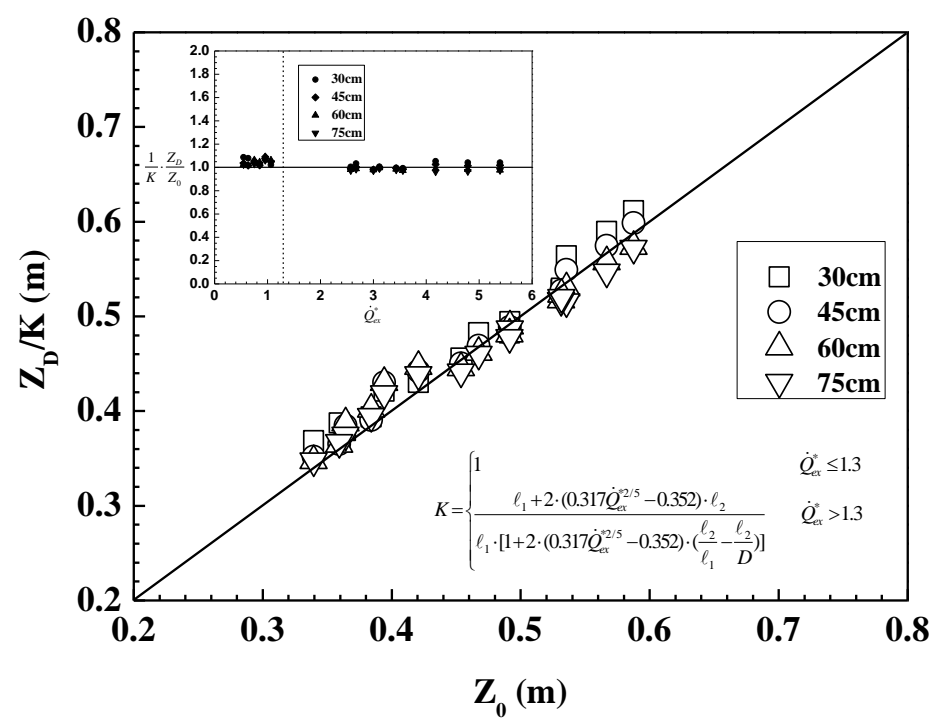

Fig. 12b. Determination of the height of the facade flames at distance D of the sidewalls (Fig. 12a) using the height when the sidewalls are absent $Z_{0}$ and the parameter $K$ which depends on the length scales $\ell_{1}, \ell_{2}$ (Eqs. 7a and 7b) and the normalized excess HRR (Eq. 8). 


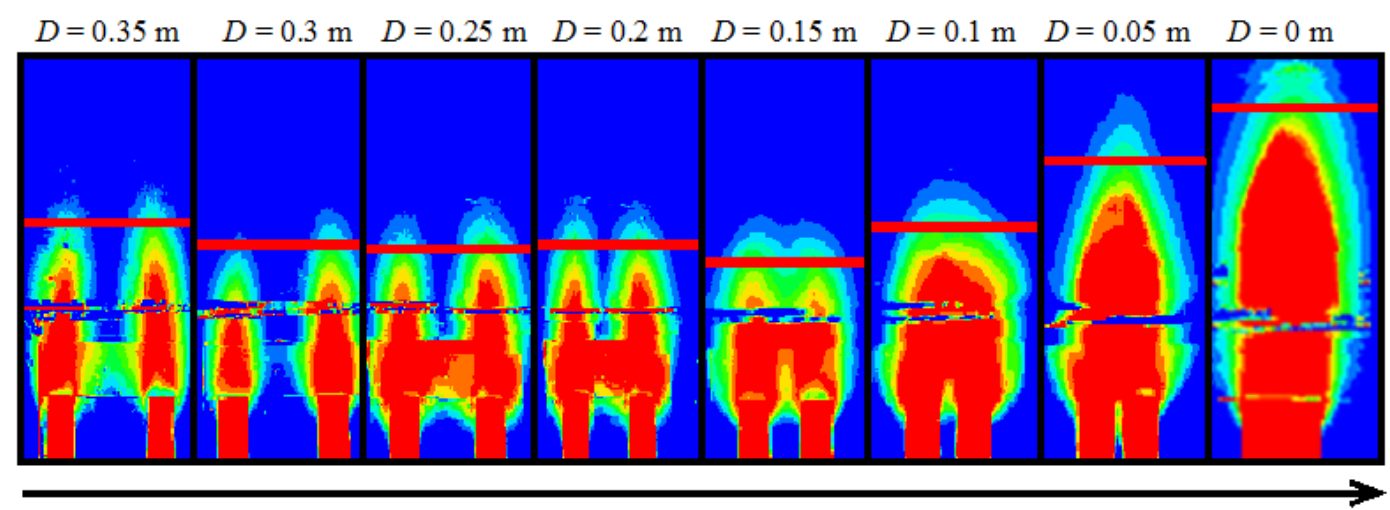

Decrease in separation distance of windows

Fig. 13a. Average contour maps of video intensity showing facade flame heights for decreasing separation distance of the window $0.25 \mathrm{~m}(\mathrm{H}) \times 0.125 \mathrm{~m}(\mathrm{~W})$ and heat release rate $164 \mathrm{~kW}$ (the horizontal red line for the flame height at $50 \%$ intermittency and the horizontal blue lines are background marks).

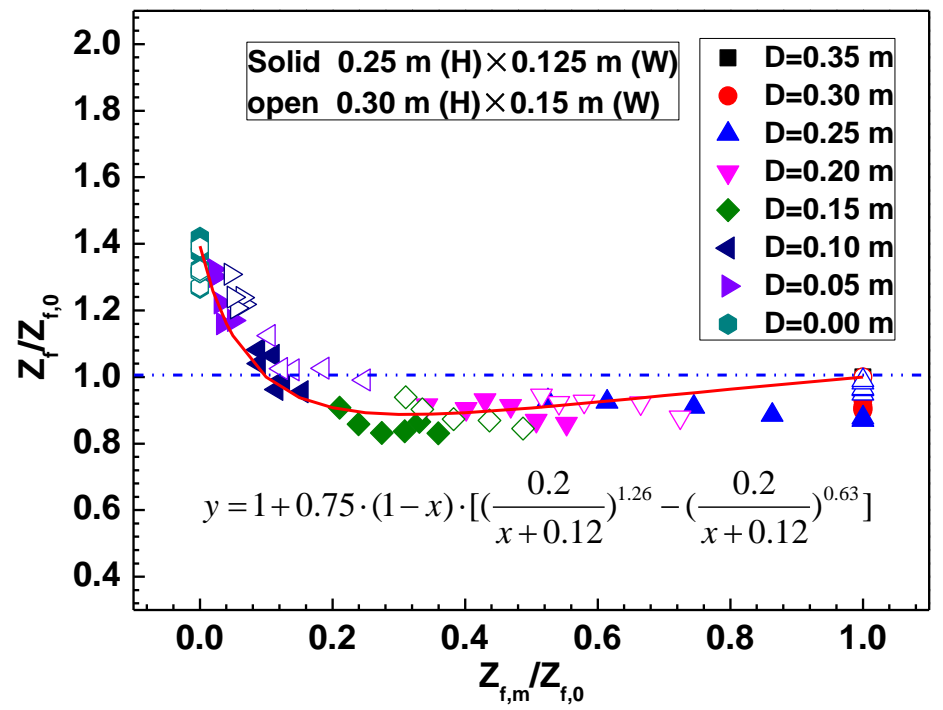

Fig. 13b. Facade flame height $Z_{f}$ against flame merging point distance $Z_{f, m}$ normalized by the completely non-merging flame height $Z_{\mathrm{f}, 0}$ where this height is reproducing the data in Fig. 10.

\section{CONCLUDING REMARKS}

There are some major challenges for enclosure and facade fires which need explanation and more experiments:

1. The (total) pyrolysis rate for normal enclosures is given by Eq. $1, \dot{m}_{T}=0.1 \sqrt{H}(\mathrm{~kg} / \mathrm{s})$ and for long corridors by Eq. $2, \dot{m}_{T}=0.025\left(2 A H^{1 / 2}\right)$ based on experiments, but there is no explanation for these values. These relations are assumed to be valid for any fuel and any geometry. Daisuke et al. [3] developed a global zone model that corroborates Eq. 1 supported also by his experiments. However, there is not a simple explanation through the equations in [3]. I propose that this behavior is due to radiation blockage near the surface of the fuel owing to pyrolysis gases. This radiation blockage is nearly inversely proportional to the concentration of pyrolysis gases in the enclosure which can be determined by the ratio of the mass pyrolysed to the air inflow:

$$
\phi \propto \frac{\dot{q}^{\prime \prime} A_{F}}{\Delta H_{p}} / \dot{m}_{a}
$$


Therefore the mass pyrolysis rate should be

$$
\dot{m}_{T} \propto \frac{\dot{q}^{\prime \prime} A_{F}}{\Delta H_{p}} / \phi \propto \dot{m}_{a}
$$

2. For a pyrolysing material Eq. 5 together with Eq. 1 provides the following excess HRR $\dot{Q}_{\text {exc }}=0.5 \Delta H_{c}(0.2-1 / S) A \sqrt{H}(\mathrm{~kW})$. This is another challenge because it proclaims that there cannot be excess HRR and excess pyrolysate $\left(\dot{Q}_{\text {exc }} / \Delta H_{c}\right)$, if the stoichiometric ratio $S<5$ !

3. The experiments used in this paper have been in small scale (up to $0.8 \mathrm{~m}^{3}$ cube) where the flow is turbulent and the conditions are under-ventilated. For these reasons, the results can be applied for larger scales as it was examined in [7] for the work of Oleszkiewicz [16] and recent results of Ohmiya [17].

4. Incorporation of wind effects requires investigation of both the magnitude of the wind and its direction. It is possible based on the present approach to examine when wind may be important by comparing the wind speed with the maximum velocity in the facade fire plume.

5. We have used CFD (mainly FDS) to model the under-ventilated fires including the facade flows but the experience has not yet been successful in predicting the experimental results.

The present results are being used for the rational design and interpretation of a test for facade assemblies that can represent well actual fuel loads and conditions for under-ventilated fires and also be economical.

\section{REFERENCES}

[1]. Delichatsios, M.A., Silcock, W.H., Liu, X., Delichatsios, M.M, and Lee, Y.P., "Mass Pyrolysis rates and Excess Pyrolysate in Fully Developed Enclosure Fires", Fire Safety Journal, Vol. 39, pp. $1-21,2004$.

[2]. Kawagoe, K., 1989. Real Fire and Fire Modeling. Fire Safety Science 2: 1-14. doi:10.3801/IAFSS.FSS.2-1

[3]. Goto, D., Ohmiya, Yoshifumi and Delichatsios, M.M., 2011. A Model for Compartment Fire Behavior Incorporating Fire Growth and Vitiation. Fire Safety Science 10: 1249-1261. 10.3801/IAFSS.FSS.10-1249

[4]. Drysdale, D., An introduction to Fire Dynamics (2nd ed.), John Wiley and Sons, Chichester, 1999

[5]. Karlsson B., Quintiere, J. G., Enclosure Fire Dynamics , CRC press, Boca Raton London New York Washington, D.C

[6]. Tofilo, P., Delichatsios, M.A., Silcock, G.W.H. and Shields, T.J., 2004. Wall Heat Fluxes in Enclosure Fires. AOFST 6

[7]. Lee, Yee-Ping, Delichatsios, M.A. and Silcock, G.W.H. "Heat fluxes and Flame heights in Facades from Fires in Enclosures of Varying Geometry", 2007 Proceedings of the Combustion Institute 31 II , pp. 2521-2528

[8]. Ohmiya, Y., Hori, Y., Sagimori, K. and Wakamatsu, T., "Predictive Method for Properties of Flame Ejected from an Opening Incorporating Excess Fuel", Proceedings of 4th Asia-Oceania Symposium on Fire Science and Technology, pp.375-386,2000.

[9]. Lee, Y.-P., Delichatsios, M.A.,Ohmiya, Y., Wakatsuki, K., Yanagisawa, A., Goto, D. Heat fluxes on opposite building wall by flames emerging from an enclosure 2009 Proceedings of the Combustion Institute 32 II , pp. 2551-2558

[10]. Yokoi, S., Japanese Ministry of Construction, Building Research Institute Report 34,1960 
[11]. Lee, Y.-P., Delichatsios, M.A., Ohmiya, Y. The physics of the outflow from the opening of an enclosure fire and re-examination of Yokoi's correlation, 2012 Fire Safety Journal 49, pp. 82-88.

[12]. Thomas PH, The size of flames from natural fires, Ninth Symposium (International) on Combustion, Academic Press, 844, 1963

[13]. Hu, L.H., Tang, F., Delichatsios, M.A., Lu, K.H. A mathematical model on lateral temperature profile of buoyant window spill plume from a compartment fire 2013 International Journal of Heat and Mass Transfer 56 (1-2), pp. 447-453

[14]. Hu, L.H., Tang, F., Delichatsios, M.A., Wang, Q., Lu, K.H., Zhang, X.C , Global behaviors of enclosure fire and facade flame heights in normal and reduced atmospheric pressures at two altitudes 2013 International Journal of Heat and Mass Transfer 56 (1-2), pp. 119-12

[15]. Tang, F., Hu, L.H., Delichatsios, M.A., Lu, K.H., Zhu, W. Experimental study on flame height and temperature profile of buoyant window spill plume from an under-ventilated compartment fire 2012, International Journal of Heat and Mass Transfer 55 (1-3) , pp. 93-101

[16]. Oleszkiewicz, I., "Heat Transfer from a Window Fire Plume to a Building Facade", HTD-Vol. 123, Collected papers in Heat Transfer, Book No. H00526, pp. 163-70, 1989.

[17]. Ohmiya, Y. Private Communication, October , 2013

\section{ACKNOWLEDGEMENTS}

This work was supported by EPSRC, supported by European programs (AIRCRAFTFIRE, ELISSA) NFPA as well as my previous and current institutions CSIRO and University of Ulster, Building Research Institute and FireSERT. I am also indebted to the following people, Jianping Zhang, Yee-Ping Lee, Piotr Tofilo, Wei Yao , Sebastian Ukleja, Tarek Beji, Mathieu Suzanne, Maurice Mckee ,technicians at FireSERT and the group of Y. Ohmiya ( TUS , Japan) and Longhua Hu( SKLFS, China, with support from National Nature Foundation of China under Grant No.51176180). 


\section{APPENDIX A}

\section{Extended literature: enclosure and facade fires}

[1]. MATEC Web Conferences ,Proceedings $1^{\text {st }}$ International Seminar for Fire Safety ,14-15 November 2013, Paris, France, where many other references can be found. http://www.matecconferences.org/index.php?option=com toc\&url=/articles/matecconf/abs/2013/0 $\underline{7 / \text { contents/contents.html }}$

[2]. Morris, J.: 'The First Interstate Bank fire - what went wrong?', Fire Prevention , No.226, January/February 1990, p 20-26. FPA Casebook of Fires, High Rise Offices, Fire Prevention No.248, April 1992, p 36-38.

[3]. Klem, T. J.: 'High-rise fire claims three Philadelphia fire fighters, NFPA Journal,

[4]. Ashton, L. A., Malhotra, H. L.: 'External walls of buildings - Part 1, The protection of openings against spread of fire from storey to storey', F. R. Note No.436, July 1960, 8pp.

[5]. Belles, D. W., Beitel, J. J.: 'Between the cracks...How fire spreads from floor to floor in a building with aluminium curtain walls', Fire Journal, May/June 1988, p 75-84.

[6]. Morris, B., Jackman, L. A.: 'Fire spread in multi-storey buildings with glazed curtain wall facades", LPR 11, 1999, 56pp.

[7]. Jackman, L., Finegan, M., Morris, B.: 'Interim report on Test 12, multi-storey test', BPSG/98/20, December 1997, 10pp.

[8]. Arvidson, M., An Initial Evaluation of Different Residential Sprinklers using HR Measurements, SP Rapport 2000:18, The Technical Research Institute of Sweden (SP), Borås, 2000.

[9]. British Standards Institution (BSI). Fire safety engineering principles for the design of buildings. BS 7974:2001, London, 2001. CAENZ, see New Zealand Centre for Advanced Engineering.

[10]. European Standard, Eurocode 1: Actions on structures - Part 1-2: General actions - Actions on structures exposed to fire, EN 1991-1-2, November 2002.

[11]. European Standard, Fire classification of construction products and building elements - Part 2: Classification using data from fire resistance tests, excluding ventilation services, EN 13501-2, 2007.

[12]. European Standard, Fixed firefighting systems. Automatic sprinkler systems. Design, installation and maintenance, EN 12845, 2009.

[13]. Fire Code Reform Centre, Fire performance of wall and ceiling lining materials, CRC Project Stage A, Fire Performance of Materials, Project Report FCRC - PR 98-02, Fire Code Reform Research Program, FCRC, Sydney, 1998.

[14]. Frantzich H. Tid för utrymning vid brand, SRV rapport P21-365/01. Statens räddningsverk, Karlstad, 2001.

[15]. Hall, J.R., U.S. Experience with Sprinklers and other Fire Extinguishing Equipment, Fire Analysis and Research Division National Fire Protection Association, February 2010.

[16]. Höglander K., Sundström B., Design fires for pre-flashover fires, SP Report 1997:36,Swedish National Testing and Research Institute, Borås, 1997.

[17]. Lougheed, G.D., Expected size of shielded fires in sprinklered office buildings, ASHRAE Transactions, Vol. 103, Pt. 1, American Society of Heating, Refrigerating and Air- Conditioning Engineers, Inc., 1997.

[18]. Lundin, J. Safety in Case of Fire - The Effects of Changing Regulations, Dept. of Fire Safety Engineering, Lund University, Lund, 2005. Case studies on the verification of fire safety design in sprinklered buildings 
[19]. McGrattan, K.B., Hostikka, S., Floyd, J., Fire Dynamic Simulator (Version 5) - User's Guide, NIST Special Publication 1019-5, National Institutes of Standards and Technology, USA, 2010.

[20]. New Zealand Centre for Advanced Engineering (CAENZ), Fire Engineering Design Guide, 3rd edition, Christchurch, 2008..

[21]. National Fire Protection Association (NFPA), Standard for the installation of sprinkler systems in residential occupancies up to and including four stories in height, NFPA 13R, Quincy, 2010.

[22]. Nordic Committee on Building Regulations (NKB), Performance Requirements for Fire Safety and Technical Guide for Verification by Calculation, Report nr. 1994:07 E, 1994.

[23]. Nystedt, F., Deaths in Residential Fires - an Analysis of Appropriate Fire Safety Measures, report 1026, Department of Fire Safety engineering, Lund University, 2003.

[24]. Nystedt, F., Verifying Fire Safety Design in Sprinklered Buildings, report 3150, Department of Fire Safety Engineering and Systems Safety, Lund University, 2011.

[25]. Nystedt, F., Frantzich, H., Kvalitetsmanual för brandtekniska analyser vid svenska kärntekniska anläggningar, report 3160, Department of Fire Safety Engineering and Systems Safety, Lund University, 2011. (In Swedish)

[26]. Platt, D.G., Fire resistance of barriers in modelling fire spread, Fire Safety Journal 22, pp.399-407, Elsevier Science Limited, 1994.

[27]. Society of Fire Protection Engineers (SFPE), SFPE Engineering Guide to Performance-Based Fire Protection, 2nd edition, Bethesda, 2007.

[28]. Suzuki, T., Sekizawa, A., Yamada, T., Yanai, E., Satoh, H., Kurioka, H., Kimura, Y., An experimental study of ejected flames of a high-rise buildings, Technical report, National Research Institute of Fire and Disaster, Japan, 2001. p. 363-73.

[29]. Trätek, Brandsäkra trähus (version 2) - nordisk kunskapsöversikt och vägledning, Publ nr0210034, Stockholm, 2002. (In Swedish)

[30]. Suzuki, T., Sekizawa, A., Yamada, T., Yanai, E., Satoh, H., Kurioka, H. and Kimura,Y., "An Experimental Study of ejected Flames of High Rise Buildings - Effects of

[31]. Depth of Balcony on Ejected Flame, "Proceedings of the Fourth Asia-Oceania Symposiumon Fire Science and Technology", Asia-Oceania Association for Fire Science and Technology, Tokyo, Japan, 2000, pp.363-373

[32]. Thomas,P.H. and Law, M., "The Projection of Flames from Burning Buildings on Fire", Fire Prevention Science and Technology No.10: 19-26 (1974)

[33]. Jansson, R. and Onnermark, B., "Flame Heights Outside Windows", National Defense Research Inst., Stockholm, Sweden FOA Report, C20445-AC, 1982

[34]. Hasemi, Y. and Izumu, J., "Leading Mechanism and General Correlation of Flames from an Opening of Fire Enclosure“, Summaries of Technical Papers of Annual Meeting Architectural Inst. of Japan, Fire safety section, (in Japanese) 1988, pp.745-746

[35]. Hägglund, B., Jansson, R. and Onnermark, B., "Fire Development in Residential Room after Ignition from Nuclear Explosions", National Defense Research Inst., Stockholm, Sweden FOA Report, C2016-D6(A3), 1974

[36]. Sugawa, O. and Takahashi, W., "Flow Behavior of Ejected Fire Flame/Plume from an Opening Effected by External Side Wind", Fire Safety Science --Proceedings of the Fifth International Symposium on Fire Safety Science, International Association of Fire Safety Science, Melbourne, Australia, 1997, pp.249-260

[37]. Takanashi, K., Suzuki,T. , Sekizawa, A., Yamada, T., Yanai, E., Satoh, H., Kurioka, H. and Kimura,Y., "Flame Configuration derived from Video Camera Picture - An Experimental Study 
of Ejected Flames of a High-rise Building Part II- “, Report of National Research Institute of Fire and Disaster No.91, Mitaka, JAPAN, 2001, pp.48-58

[38]. Bøhm, B. and Rasmussen, B.M., "The Development of a Small-scale Fire Compartment in order to Determine Thermal Exposure Inside and Outside Buildings", Fire Safety Journal, 12 : 103-108 (1987)

[39]. Suzuki, H. "Fire Safety Performance of Material and Products". Fire Handbook - Kasai Binran(3rd ed.) ,(in Japanese), Japan Association for Fire Science and Engineering, 1997, p.803

[40]. Fleischmann, C.N. and Parkes, A.R., "Effects of Ventilation on the Compartment enhanced Mass Loss Rate", Fire Safety Science -- Proceedings of the Fifth International Symposium on Fire Safety Science, International Association of Fire Safety Science, Melbourne, Australia, 1997, pp. 415-426

[41]. Law, M. and O'Brien, T. (1989), Fire safety of bare external structural steel, The Steel Construction Institute, SCI Publication 009, U.K. ISBN: 0862000262.

[42]. BSI (2002), Eurocode 1: Actions on structures - Part 1-2: General actions - Actions on structures exposed to fire, British Standards, U.K. BS EN 1991-1-2:2002.

[43]. Balter, M. (2004), Earliest signs of human-controlled fire uncovered in Israel, Science 304 (5671), pp.663 - 665 .

[44]. Plato (ca. 360 BC) Timaeus, translated by W.R.M. Lamb in Plato in Twelve Volumes (9), Cambridge, MA, Harvard University Press; London, William Heinemann Ltd.

[45]. Richardson, J.K., (Ed.) (2003), History of Fire Protection Engineering, National Fire Protection Association, Inc., Massachusetts, USA.

[46]. Emmons, H.W. (1984), The further history of fire science, Combustion Science and Technology 40, pp.167-174. Gordon and Breach Science Publishers.

[47]. Cote, A.E. (2008), History of fire protection engineering, Fire Protection Engineering (10 Year magazine), Fall of 2008, Society of Fire Protection Engineers, U.S.A., pp.28-36.

[48]. Beyler, C. (1999), Guest editorial: Professor Howard Emmons 1912-1998, Fire Technology 35 (1), pp.1-3.

[49]. Trouvé A. (2007), Challenges in CFD modeling of large-scale pool fires, Proceedings of Advanced Research Workshop on Fire Computer Modeling, (Ed.) J. A. Capote Abreu, GIDAI, Univ. Cantabria, Santander, Spain, pp.1-14.

[50]. BBC (2007), Skyscraper Fire Fighters (documentary), BBC Horizon, U.K. www.bbc.co.uk/sn/tvradio/programmes/horizon/broadband/tx/firegrid/ [accessed 16/09/2009]

[51]. McAllister, T., Barnett, J., Gross, J., Hamburger, R., Magnusson, J. (2002), World Trade Center building performance study: data collection, preliminary observations and recommendations, Chapter 1: Introduction, Technical Report FEMA 403, Federa Emergency Management Agency, Washington, D.C., U.S.A.

[52]. Usmani, A.S., Chung, Y.C. and Torero, J.L. (2003), How did the WTC towers collapse: anew theory, Fire Safety Journal 38 (6), pp.501-533.

[53]. Quintiere, J.G. (1989), Scaling applications in fire research, Fire Safety Journal 15 (1), pp.3-29.

[54]. Ma, T.G. and Quintiere, J.G. (2003), Numerical simulation of axi-symmetric fire plumes: accuracy and limitations, Fire Safety Journal 38 (5), pp.467-492.

[55]. Rein, G., Torero, J.L., Wolfram, J., Stern-Gottfried, J., Ryder, N.L., Desanghere, S., Lázaro, M., Mowrer, F., Coles, A., Joyeux, D., Alvear, D., Capote, J.A., Jowsey, A., Abecassis- Empis, C. and Reszka, P. (2009), Round-robin study of a priori modelling predictions of the Dalmarnock Fire Test One, Fire Safety Journal 44 (4), pp.590-602 
[56]. Jahn, W., Rein, G. and Torero, J.L. (2007), Posteriori modelling of Fire Test One, Chapter 11, The Dalmarnock Fire Tests: Experiments and Modelling, (Eds.) Rein, G., Abecassis Empis, C. and Carvel, R., School of Engineering and Electronics, The University of Edinburgh, U.K. ISBN 978 0-9557497-0-4.

[57]. Fernandez-Pello, A.C. (1994), The solid phase, Chapter 2, Combustion Fundamentals of Fire, (Ed.) G. Cox, Academic Press, pp.31-100.

[58]. NFPA (2003), Fire Protection Handbook, 19th Edition, National Fire Protection Association, U.S.A.

[59]. BSI (2001), Application of fire safety engineering principles to the design of buildings - Code of Practice, British Standards, U.K. BS 7974:2001.

[60]. Cowlard, A., Jahn, W., Abecassis-Empis, C., Rein, G. and Torero, J.L. (2010), Sensor assisted fire fighting, Fire Technology, 46 (3), pp.719-741.

[61]. Upadhyay, R., Pringle, G., Beckett, G., Potter, S., Han, L., Welch, S., Usmani, A. And Torero, J. (2009), An architecture for an integrated fire emergency response system for the built environment, Fire Safety Science 9, pp.427-438.

[62]. Law, M. (1978), Fire safety of external building elements - The design approach, Engineering Journal, Second Quarter, pp.59-74, American Institute of Steel Construction (AISC), U.S.A.

[63]. Law, M. (1981), Designing fire safety for steel - recent work, ASCE Spring Convention, American Society of Civil Engineers, U.S.A.

[64]. Tonkelaar, E. den (2003), Prediction of the effect of breaking windows in a double skin facade as a result of fire, Eighth International IBPSA Conference, Eindhoven, Netherlands.

[65]. Colwell, S. and Martin, B. (2003), Fire performance of external thermal insulation for walls of multi-storey buildings, BR 135, Building Research Establishment (BRE), U.K. ISBN 1- 86081622-3.

[66]. Read, R. E. H. (1991), External fire spread: building separation and boundary distances, BR187, Building Research Establishment (BRE), U.K.

[67]. Johnson, C. and Tarlin, E. (1974), Incêndio (film), National Fire Protection Association and the National Bureau of Standards, U.S. Department of Commerce.

[68]. Routley, J., Jennings, C. and Chubb, M. (1991) High-rise office building fire, One Meridian Plaza, Philadelphia, Penn., February 23, 1991, United States Fire Administration, Technical Report Series, Report 049, FEMA, U.S.A.

[69]. Kenichi, I. and Sekizawa, A. (2005), Collapse mechanism of the Windsor building by fire in Madrid and the plan for its demolition process, International Workshop on Emergency Response and Rescue 2005, Taiwan.

[70]. Jacobs, A. (2009), Fire ravages renowned building in Beijing, The New York Times (Feb. 10th 2009), New York Edition, U.S.A.

[71]. Soares, G. (2010), Incêndio danifica hotel de 25 milhões, Diário de Notícias (10th March 2010), Portugal.

[72]. Cunha, S. (2010), Braga: Incêndio destrói parte da fachada de hotel, Correio da Manhã (9 $9^{\text {th }}$ March 2010), Portugal.

[73]. Cooke, G. (2009), Andraus high-rise, São Paulo, Brazil, February 1972 (presentation), Fire Safety Consultant London 2009, http://www.cookeonfire.com/pdfs/Andraus\%20pdf.pdf [03/02/2010]

[74]. Tavares, R. M. (2008), Prescriptive codes vs. performance-based codes: Which one is the best fire safety code for the Brazilian context?, Safety Science Monitor 12 (1), Australia.

[75]. Beitel, J. and Iwankiw, N. (2002), Analysis of needs and existing capabilities for full-scale fire resistance testing, NIST GCR 02-843, National Institute of Standards and Technology, U.S.A. 
[76]. Demers, D. P. (1981), Hotel fire, Las Vegas, NV, February 10, 1981, NFPA Fire Investigation, National Fire Protection Association, Quincy, MA, U.S.A.

[77]. O’Connor, D. J. (2008), Building facade or fire safety facade? CTBUH 8th World Congress, Dubai. Knight, K. (2009), Report to the Secretary of State by the Chief Fire and Rescue Adviser on the emerging issues arising from the fatal fire at Lakanal House, Camberwell on 3 July 2009, communities and Local Government, London, UK. ISBN 978-1-4098-1175-8.

[78]. Ingberg, S. H. (1928), Test of the severity of building fires, National Fire Protection Association Quarterly, 22 (1), pp.43-61.

[79]. Fujita, K. (1958), Characteristics of fire inside a non-combustible room and prevention of fire damage, Report 2 (2), Japanese Ministry of Construction, Building Research Institute, Tokyo, Japan.

[80]. Kawagoe, K. (1958), Fire behaviour in rooms, Report 27, Building Research Institute, Tokyo, Japan.

[81]. Thomas, P.H. and Law, M. (1972), The projection of flames from burning buildings, FRN 921, Fire Research Station, Borehamwood, U.K.

[82]. Thomas, P.H. and Heselden, A.J.M. (1972), Fully-developed fires in single compartments - A cooperative research programme of the Conseil International du Bâtiment, CIB Report No.20, FRN 923, Fire Research Station, Borehamwood, U.K.

[83]. Thomas, P.H. (1974), Fires in model rooms: CIB research programmes, Building Research Establishment Current Paper CP32/74, BRR, Borehamwood, U.K.

[84]. Magnusson, S.E. and Thelandersson, S. (1970), Temperature-time curves of complete process of fire development. Theoretical study of wood fuel fires in enclosed spaces, Acta Polytechnica Scandinavia, Civil Engineering and Building Construction Series 65, Stockholm, Sweden.

[85]. Babrauskas, V. and Williamson, R.B. (1978), Post-flashover compartment fires: Basis of a theoretical model, Fire and Materials 2 (2), pp.39-53.

[86]. Babrauskas, V. (1981), A closed-form approximation for post-flashover compartment fire temperatures, Fire Safety Journal 4, pp.63-73.

[87]. Yokoi, S. (1960), Study on the prevention of fire-spread caused by hot upward current, Building Research Institute, Report No. 34, Tokyo, Japan.

[88]. Webster, C.T. and Raftery, M.M. (1959), The burning of fires in rooms - Part II, FRN 401, Joint Fire Research Organization, Borehamwood, U.K.

[89]. Webster, C.T., Raftery, M.M., and Smith, P.G. (1961), The burning of fires in rooms - Part III, FRN 474, Joint Fire Research Organization, Borehamwood, U.K.

[90]. Webster, C.T. and Smith, P.G. (1964), The burning of well-ventilated compartment fires - Part IV brick compartment, 2.4 m (8 ft) cube, FRN 578, Joint Fire Research Organization, Borehamwood, U.K.

[91]. Thomas, P. H. (1961), On the heights of buoyant flames, FRN 489, Fire Research Station, Borehamwood, U.K.

[92]. Seigel, L.G. (1969), The projection of flames from burning buildings, Fire Technology 5 (1), pp.43-51.

[93]. Heselden, A.J.M., Smith, P.G. and Theobald, C.R. (1966), Fires in a large compartment containing structural steelwork - Detailed measurements of fire behaviour, FRN 646, Fire Research Station, Borehamwood, U.K.

[94]. Gross, D. (1967), Field burnout tests of apartment dwelling units, Building Science Series 10, National Bureau of Standards, Sept. 29. 
[95]. Underwriters Laboratories, Inc. (1970), Fire test of Walt Disney World unitized guest room, report for United States Steel Corporation, Underwriters Laboratories, Inc., July 1, Illinois, U.S.A.

[96]. Butcher, E.G., Chitty, T.B. and Ashton, L.A. (1966), The temperature attained by steel in building fires, Fire Research Technical Paper 15, HMSO, London, U.K.

[97]. Underwriters Laboratories, Inc. (1975), Fire severity at the exterior of a burning building, American Iron and Steel Institute, April 3, Washington, D.C., U.S.A.

[98]. Stromdahl, I. (1972), The Tranas Fire Tests - Field studies of heat radiation from fires in a timber structure, National Swedish Institute for Building Research, Document D3, Stockholm, Sweden.

[99]. Kordina, K. (1978), Brandversuche Lehrte - Schriftenreihe "Bau und Wohnforschung" des Bundesministers für Raumordnung, Bauwesen und Städtebau, Bonn, Germany.

[100]. Buchanan, A.H. (2002), Structural Design for Fire Safety, John Wiley \& Sons, U.K. ISBN: 0-47189060-X.

[101]. Thomas, P.H. (1963), The size of flames from natural fires, Symposium (International) on Combustion 9 (1), pp.844-859.

[102]. Bullen, M.L. and Thomas, P.H. (1979), Compartment fires with non-cellulosic fuels, Proceedings of the 17th Symposium (International) on Combustion 17 (1), pp.1139-1148, The Combustion Institute, U.S.A.

[103]. Bohm, B. and Rasmussen, B.M. (1987), The development of a small-scale fire compartment in order to determine thermal exposure inside and outside buildings, Fire Safety Journal 12 (2), pp.103-108.

[104]. Oleszkiewicz, I. (1989), Heat transfer from a window fire plume to a building facade, HTD 123, ASME Collected papers on Heat Transfer, Book No. H00526, pp.163-170.

[105]. Oleszkiewicz, I. (1990), Fire exposure to exterior walls and flame spread on combustible cladding, Fire Technology 26, pp.357-375.

[106]. Oleszkiewicz, I. (1991), Vertical separation of windows using spandrel walls and horizontal projections, Fire Technology 27, pp.334-340.

[107]. Gottuk, D.T., Roby, R.J. and Beyler, C.L. (1992), A study of carbon monoxide and smoke yields from compartment fires with external burning, Symposium (International) on Combustion 24 (1), pp.1729-1735.

[108]. Ohmiya, Y., Yusa, S., Suzuki, J.I., Koshikawa, K. and Delichatsios, M.A. (2003), Aerodynamics of fully involved enclosure fires having external flames, Proceedings of the Fourth International Seminar on Fire and Explosion Hazards, University of Ulster, Belfast, U.K.

[109]. Ohmiya, Y., Tanaka, T. and Wakamatsu, T. (1998), A room fire model for predicting fire spread by external flames, Fire Science and Technology 18 (1), pp.11-21.

[110]. Ohmiya, Y., Hori, Y., Sagimori, K. and Wakamatsu, T. (2000), Predictive method for properties of flame ejected from an opening incorporating excess fuel, Proceedings of the Fourth AsiaOceania Symposium on Fire Science and Technology, pp. 375-386.

[111]. Lee, Y.-P., Delichatsios, M.A. and Silcock, G.W.H. (2007), Heat fluxes and flame heights in facades from fires in enclosures of varying geometry, Proceedings of the Combustion Institute 31 (2), pp.2521-2528.

[112]. Lee, Y.-P. (2006), Heat fluxes and flame heights in external facades from enclosure fires, Ph.D. Thesis, The University of Ulster, Belfast, U.K.

[113]. Goble, K. (2007), Height of flames projecting from compartment openings, Masters Thesis, The University of Canterbury, Christchurch, New Zealand.

[114]. Klopovic, S. and Turan, Ö.F. (1998), Flames venting externally during full-scale flashover fires: Two sample ventilation cases, Fire Safety Journal 31 (2), pp.117-142. 
[115]. Klopovic, S. and Turan, Ö.F. (2001) A comprehensive study of externally venting flames - Part I: External plume characteristics for through-draught and no-through-draught ventilation conditions and repeatability, Fire Safety Journal 36 (2), pp.99-133.

[116]. Klopovic, S. and Turan, Ö.F. (2001), A comprehensive study of externally venting flames - Part II: Plume envelope and centre-line temperature comparisons, secondary fires, wind effects and smoke management system, Fire Safety Journal 36 (2), pp.135-172.

[117]. Suzuki, T., Sekizawa, A., Satoh, H., Yamada, T., Yanai, E., Kurioka, H. and Kimura, Y. (1999), An experimental study of ejected flames of a high-rise building Part I, National Research Institute of Fire and Disaster No.88, Japan, pp.51-63.

[118]. Takahashi, K., Suzuki, T., Yamada, T., Yanai, E., Sekizawa, A., Kurioka, H. and Satoh, H. (2001), Flame configuration derived from video camera picture - An experimental study of ejected flames of a high-rise building Part II, National Research Institute of Fire and Disaster No.91, Japan, pp.48-58.

[119]. Yamada, T., Takahashi, K., Yanai, E., Suziki, T., Sekizawa, A., Satoh, H. and Kurioka, H. (2001), Heat flux to surface walls above fire floor level - An experimental study of ejected flames of a high-rise building Part III, National Research Institute of Fire and Disaster No.88, Japan, pp.5968.

[120]. Hakkarainen, T. and Oksanen, T. (2002), Fire safety assessment of wooden facades, Fire and Materials 26, pp.7-27.

[121]. Sugawa, O., Momita, D. and Takahashi, W. (1996), Flow behaviour of ejected fire flame/plume from an opening effected by external side wind, Proceedings of the $5^{\text {th }}$ International Syposium on Fire Safety Science, pp.249-260.

[122]. ARUP, Innovator's hall of fame, Short biography of "Margaret Law", http://info.arup.com/arup/feature.cfm?pageid=8984 [accessed 05/03/09]

[123]. Incropera, F.P. and DeWitt, D.P. (2002), Fundamentals of Mass and Heat Transfer, Fifth Edition, John Wiley \& Sons, Inc., U.S.A. ISBN: 0-471-38650-2.

[124]. Arnault, P., Ehm, H. and Kruppa, J. (1973), Rapport experimental sur les essays avec des feux naturels executes dans la petite installation, CECM 3/73-11-F, CTICM, Puteaux, France.

[125]. Howell, J.R. (1982), A catalog of radiation heat transfer configuration factors, 3rd Edition, The University of Texas at Austin, Austin, Texas, U.S.A. http://www.engr.uky.edu/rtl/Catalog/ [accessed 07/09/2008]

[126]. McGuire, J.H. (1952), The calculation of heat transfer by radiation, FRN 20, Fire Research Station, Borehamwood, U.K.

[127]. BSI (1972), BS476: Part 20: 1987 - Fire tests on building materials and structures: Methods for determination of the fire resistance of elements of construction (general principles), British Standards, U.K.

[128]. BSI (1972), BS476: Part 21: 1987 - Fire tests on building materials and structures: Methods for determination of the fire resistance of load bearing elements of construction, British Standards, U.K.

[129]. BSI (1972), BS476: Part 8: 1972 - Fire tests on building materials and structures: Test methods and criteria for the fire resistance of elements of building construction, British Standards, U.K.

[130]. Seigel, L.G. (1970), Fire test of an exposed steel spandrel girder, Materials Research and Standards, MTRSA 10 (2), pp.10-13.

[131]. Arnault, P., Ehm, H. and Kruppa, J. (1974), Evolution des temperatures dans des poteaux exterieurs soumis a des incendices, CECM 3-74/7F, CTICM, Puteaux, France.

[132]. Law, M. (1981/2), Notes on the external fire exposure measured at Lehrte, Fire Safety Journal 4 (4), pp.243-246, Elsevier Science, U.K. 
[133]. Ashton, L.A. and Malhotra, H.L. (1960), External walls on buildings, I - The protection of openings against spread of fire from storey to storey, FRN 836, Borehamwood, U.K.

[134]. Moulen, A.W. (1971), Horizontal projections in the prevention of spread of fire from storey to storey, Report TR52/75/397, Commonwealth Experimental Building Station, Australia.

[135]. Harmathy, T.Z. (1979), Design to cope with fully developed compartment fires, in Design of Buildings for Fire Safety, (Eds.) E.E. Smith and T.Z. Harmathy, American Society for Testing and Materials, STP 685, pp.198-276.

[136]. Becker, R. (2002), Structural behaviour of simple steel structures with non-uniform longitudinal temperature distributions under fire conditions, Fire Safety Journal 37 (5), pp.495-515.

[137]. Gillie, M., Usmani, A.S. and Rotter, J.M. (2002), A structural analysis of the Cardington British Steel Corner Test, Journal of Construction Steel Research 58 (4), pp.427-442.

[138]. Welch, S. and Lennon, T. (2001), Comments on Eurocode 1 - Actions on structures, Part 1- 2: General actions - actions on structures exposed to fire, Amended FINAL DRAFT (Stage34), 24 August 2001, BRE, U.K.

[139]. Reszka, P., Abecassis Empis, C., Biteau, H., Cowlard, A., Steinhaus, T., Fletcher, I.A., Fuentes, A., Gillie, M. and Welch, S. (2007), Experimental layout and building description, Chapter 2, The Dalmarnock Fire Tests: Experiments and Modelling, (Eds.) Rein, G., Abecassis Empis, C. and Carvel, R., School of Engineering and Electronics, The University of Edinburgh, U.K. ISBN 9780-9557497-0-

[140]. Cowlard, A., Steinhaus, T., Abecassis Empis, C. and Torero, J.L. (2007), Test Two: The 'Controlled fire', Chapter 4, The Dalmarnock Fire Tests: Experiments and Modelling, (Eds.) Rein, G., Abecassis Empis, C. and Carvel, R., School of Engineering and Electronics, The University of Edinburgh, U.K. ISBN 978-0-9557497-0-4.

[141]. Amundarain, A.A, Torero, J.L., Usmani, A., Al-Remal, A.M. (2007), Assessment of the thermal efficiency, structure and fire resistance of lightweight building systems for optimised design, $\mathrm{PhD}$ Thesis, School of Engineering, The University of Edinburgh, U.K. http://hdl.handle.net/1842/2128 [accessed 01/04/2008].

[142]. Jowsey, A., Torero, J.L., and Lane, B. (2007), Heat transfer to the structure during the Fire, Chapter 7, The Dalmarnock Fire Tests: Experiments and Modelling, (Eds.) Rein, G., Abecassis Empis, C. and Carvel, R., School of Engineering and Electronics, The University of Edinburgh, U.K. ISBN 978-0-9557497-0-4.

[143]. Gillie, M. and Stratford, T. (2007), Behaviour of the structure during the fire, Chapter 8, The Dalmarnock Fire Tests: Experiments and Modelling, (Eds.) Rein, G., Abecassis Empis,mC. and Carvel, R., School of Engineering and Electronics, The University of Edinburgh, U.K. ISBN 978 0-9557497-0

[144]. Stratford, T., Gillie, M. and Chen, J-F. (2007), The performance of fibre reinforced polymer strengthening in the fire, Chapter 9, The Dalmarnock Fire Tests: Experiments and Modelling, (Eds.) Rein, G., Abecassis Empis, C. and Carvel, R., School of Engineering and Electronics, The University of Edinburgh, U.K. ISBN 978-0-9557497-0-4.

[145]. Welch, S., Jowsey, A., Deeny, S., Morgan, R. and Torero, J.L. (2007), BRE large compartment fire tests - characterising post-flashover fires for model validation, Fire Safety Journal 42 (8), pp.548-567. doi:10.1016/j.firesaf.2007.04.002.

[146]. Jin, T. (2008), Visibility and human behaviour in fire smoke, The SFPE Handbook of Fire Protection Engineering, 4th Edition, (Eds.) P.J. DiNenno et al., National Fire Protection Association, Massachusetts, U.S.A., pp. 2-54 - 2-66.

[147]. Abecassis Empis, C., Cowlard, A., Welch, S. and Torero, J.L. (2007), Test One: The 'Uncontrolled' fire, Chapter 3, The Dalmarnock Fire Tests: Experiments and Modelling, (Eds.) Rein, G., Abecassis Empis, C. and Carvel, R., School of Engineering and Electronics, The University of Edinburgh, U.K. ISBN 978-0-9557497-0-4. 
[148]. Mulholland, G.W. (2002), Smoke production and properties, The SFPE Handbook of Fire Protection Engineering, 3rd Edition, (Eds.) P.J. DiNenno et al., National Fire Protection Association, Massachusetts, U.S.A, pp. 2-291-2-302.

[149]. Ingason, H. and Wickstrom, U. (2007), Measuring incident radiant heat flux using the plate thermometer, Fire Safety Journal 42 (2), pp.161-166.

[150]. ASTM (2005), ASTM E459 - 05: Standard test method for measuring heat transfer rate using a thin-skin calorimeter, ASTM International, U.S.A. DOI: 10.1520/E0459-05.

[151]. McCaffrey, B.J., Heskestad, G. (1979), A robust bidirectional low-velocity probe for flame and fire application, Combustion and Flame 26 (1), pp.125-127.

[152]. Cowlard, A. (2009), Sensor and model integration for the rapid prediction of concurrent flow flame spread, $\mathrm{PhD}$ Thesis, School of Engineering, The University of Edinburgh, U.K. http://hdl.handle.net/1842/2753 [accessed 18/09/2009].

[153]. Huggett, C. (1980), Estimation of rate of heat release by means of oxygen consumption measurements, Fire and Materials 4, pp.61-65.

[154]. Kawagoe, K. and Sekine, T. (1963), Estimation of fire temperature-time curve in rooms, BRI Occasional Report 11, Building Research Institute, Tokyo, Japan.

[155]. BSI (1993), BS 476: Part 33: 1993 (ISO 9705:1993) - Fire tests on building materials and structures: full-scale room test for surface products, British Standards, U.K.

[156]. Babrauskas, V. (1981), Will the second item ignite?, National Bureau of Standards, Gaithersburg, MD, U.S.A. NBSIR 81-2271.

[157]. Joshi, A. and Pagni, P.J. (1990), Thermal analysis of effect of a compartment fire on window glass, Fire Research and Safety, 11th Joint Panel Meeting, (Eds.) Jason, N. H., Cramer, D. M., , Berkeley, CA, pp. 233-252.

[158]. Mowrer, F.W. (1997), Window breakage induced by exterior fires, Proceedings of the $2^{\text {nd }}$ International Conference on Fire Research and Engineering (ICFRE2), NIST and SFPE sponsored, Gaithersburg, MD, U.S.A.

[159]. Desanghere, S. (2007), Development of a simplified model aimed at predicting external members heating conditions, Interflam 2007 - Proceedings of the Eleventh International Conference (2), Interscience Communications, London, UK., pp. 955-966. 


\section{APPENDIX B}

\section{Length scales for the convective flow outside the enclosure}

We have revised Yokoi's [10] work for the gas temperature distribution along a facade to introduce a length scale that would better collapse the experimental data. Namely, Yokoi [10] proposed to use the square root of the area, $\sqrt{H W}$, of the enclosure opening as an effective length scale for the thermal plume in the facade produced by over-ventilated fires with no combustion occurring outside. Examination of his analysis would show that the appropriate scale should have been $(A \sqrt{H})^{2 / 5}$ instead. Replotting his data in ref. 10, see also our work in [11] verifies this conclusion but because of lack of space we chose not to insert the full explanation and this plot here. Figure B1 illustrates the physical meaning of the scales introduced for the flow issuing at the opening of an enclosure.

Nevertheless, we show in this work how and why this scale is significant for the analysis of flames on facades at under-ventilated conditions. Namely, the convective flow at the exit is defined as:

$$
\begin{aligned}
\dot{Q}_{\text {conv }}^{\prime \prime} & =\dot{m}_{g}\left(\approx \dot{m}_{a}\right) C_{p} \Delta T_{g}=0.5 A \sqrt{H} C_{p} \Delta T_{g} \\
& =\left(\frac{0.5}{\rho_{\infty} \sqrt{g}}\right) \rho_{\infty} A \sqrt{H g} C_{p} \Delta T_{g}=0.13 \rho_{\infty} A \sqrt{H g} C_{p} \Delta T_{g}
\end{aligned}
$$

or

$$
\left(\frac{\Delta T_{g}}{T_{\infty}}\right)=0.025 \frac{\dot{Q}_{c o n v}^{\prime \prime}}{\rho_{\infty} C_{p} \Delta T_{\infty} \sqrt{g}(A \sqrt{H})}
$$

which indicates that an appropriate length scale is:

$$
\ell_{1}=(A \sqrt{H})^{2 / 5}
$$

Moreover, an important characteristic (different from other wall fires) of the flows outside the enclosure is that they are ejected horizontally before turning vertically and attaching to the facade. The horizontal length after which the flow becomes vertical can be determined from the momentum and buoyancy at the exit of the enclosure. Specifically, the momentum flux is equal to:

$$
M_{o} \approx \dot{m}_{g} u
$$

and the buoyancy flux

$$
J_{o} \approx \dot{m}_{g} \frac{\Delta T_{g}}{T_{\infty}} g
$$

where the characteristic exit velocity and the mass flow are:

$$
u \propto \sqrt{\frac{\Delta T_{g}}{T_{\infty}} g H} \text { and } \dot{m}_{g}\left(=\dot{m}_{a}\right) \propto \rho_{\infty} u A
$$


The characteristic length after which buoyancy dominates is determined by equating the momentum at the origin with the momentum of the developing thermal plume generated by the buoyancy flux after a certain distance:

$$
\ell_{2}=\frac{\left(M_{o} / \rho_{\infty}\right)^{3 / 4}}{\left(J_{o} / \rho_{\infty}\right)^{1 / 2}}=\left[A H^{2}\right]^{1 / 4}
$$

It is concluded that the length scales $\ell_{1}=(A \sqrt{H})^{2 / 5}$ and $\ell_{2}=\left(A H^{2}\right)^{1 / 4}$ underpin the physics related to the flow at the exit of the enclosure. More specifically, the flow outside the enclosure may be depicted as generated by a rectangular burner having sides $\ell_{1}$ and $\ell_{2}$ (normal to the opening plane) at the level of the neutral plane and providing unburned gas of chemical energy $\dot{Q}_{e x}$.

We chose the length scale $\ell_{1}$ to correlate the flame height and heat fluxes on the facade because we can observe that $\ell_{2}$ is nearly proportional to $\ell_{1}$ varying weakly with aspect ratio of the window, i.e.,

$$
\frac{\ell_{2}}{\ell_{1}}=\left(\frac{H}{W}\right)^{3 / 20}
$$

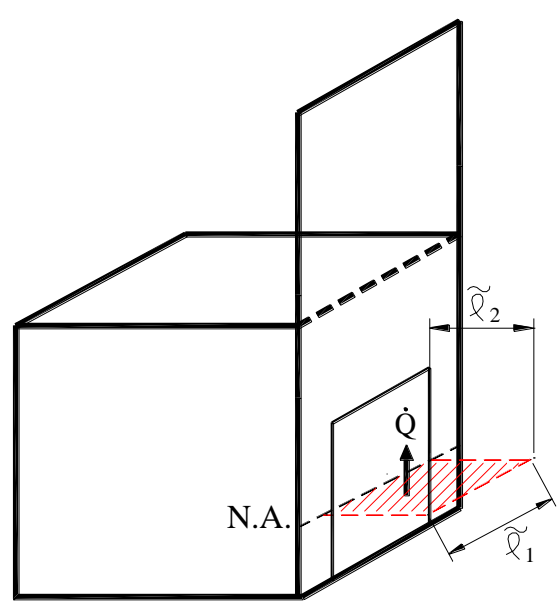

Figure B1 A sketch of the physical meaning of length scales $\tilde{\ell}_{1}$ and $\tilde{\ell}_{2}$

\section{APPENDIX C}

\section{Length scales representing the length after which the flames turns from horizontal to vertical}

A length scale for the under-ventilated fires with flame ejecting outside the opening representing the length after which the flames turns from horizontal to vertical due to buoyancy $\left(\ell_{3}\right)$, are presented below. The horizontal length after which the flames become vertical can be determined by the competition of momentum and buoyancy in the vicinity of the opening.

The upward momentum due to the entrainment can be expressed as:

$$
M_{e n t} \propto \rho_{\infty}\left(\sqrt{\frac{\Delta T_{f}}{T_{\infty}} g \ell_{3}}\right) \ell_{3} \ell_{1}\left(\sqrt{\frac{\Delta T_{f}}{T_{\infty}} g \ell_{3}}\right)
$$


where:

$\Delta \mathrm{T}_{\mathrm{f}}$ is the temperature rise between flame and ambient.

$\rho_{\infty}$ and $T_{\infty}$ are the density and temperature of ambient air, respectively.

$\ell_{3}$ is the distance of flames ejecting from the opening after from horizontal to vertical.

$\ell_{1}=\left(\mathrm{AH}^{1 / 2}\right)^{2 / 5}$ is the length representing the exit condition of the enclosure (Appendix $\mathrm{B}$ )

The horizontal momentum flux at the exit $\mathrm{M}_{0}$ is equal to:

$M_{0} \approx \rho_{g} \frac{\Delta T_{g}}{T_{\infty}}\left(H-Z_{o}\right)^{2} g W$

where: $\mathrm{W}$ is the width of the opening

$\Delta \mathrm{T}_{\mathrm{g}}$ is the temperature rise between gas inside the enclosure and ambient

$\mathrm{Z}_{\mathrm{o}}$ is the distance between the neutral plane and bottom of the opening

The characteristic length $\ell_{3}$ after which buoyancy dominates is defined by equating the horizontal momentum at the origin (Eq. C2) with the vertical momentum (Eq. C1) generated by the buoyancy

$M_{e n t}=\rho_{\infty} \frac{\Delta T_{f}}{T_{\infty}} g \ell_{3}^{2} \ell_{1} \approx \rho_{g} \frac{\Delta T_{g}}{T_{\infty}}\left(H-Z_{o}\right)^{2} g W=M_{0}$

Inserting $\ell_{1}=\left(A H^{1 / 2}\right)^{2 / 5}$ in Eq. $\mathrm{C} 3$ and making arrangement, it gives

$\ell_{3} \propto\left(\frac{\Delta T_{g}}{\Delta T_{f}}\right)^{1 / 2}\left(\frac{\rho_{g}}{\rho_{\infty}}\right)^{1 / 2}\left(1-\frac{Z_{o}}{H}\right)\left(A H^{4 / 3}\right)^{3 / 10}$

In the case of under-ventilated fire condition, Eq. C 4 can be expressed as [1]:

$\ell_{3} \propto\left(\frac{\Delta T_{g}}{\Delta T_{f}}\right)^{1 / 2}\left(\frac{\rho_{g}}{\rho_{\infty}}\right)^{1 / 2}\left(1-\frac{1}{1+\left(\frac{\rho_{\infty}}{\rho_{g}}\right)^{1 / 3}}\right)\left(A H^{4 / 3}\right)^{3 / 10}$

In under-ventilated fire, the effect of enclosure gas temperature and temperature of flames (assume $\Delta T_{f} \approx 2000 \mathrm{~K}$ ) on the length scale $\ell_{3}$ was examined by the cases having gas temperature $600{ }^{\circ} \mathrm{C}$ and $1000^{\circ} \mathrm{C}$, respectively. It is observed that the length scale $\ell_{3}$ is independent on the gas temperature inside the enclosure for the case of under-ventilated fire condition. Thus, the length after which the flames turn from horizontal to vertical for the case with flames appear outside of the enclosure can be expressed as

$\ell_{3} \propto\left(A H^{4 / 3}\right)^{3 / 10}$ 


\section{APPENDIX D:}

Phil Thomas query of the Yokoi relation $[10,11]$

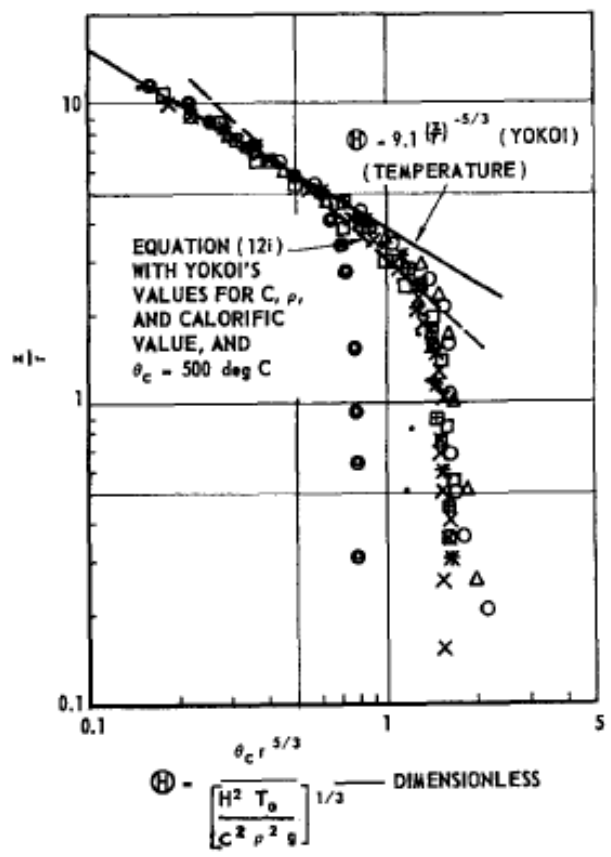

CONTINUOUS HEAT SOURCES

\begin{tabular}{|c|c|}
\hline SYMBOL & $\frac{r}{\mathrm{~cm}}$ \\
\hline$\bullet$ & 3.3 \\
\hline & 6 \\
$\times$ & 9.9 \\
$\mathrm{O}$ & 14.3 \\
$\square$ & 18.75 \\
由 & 23.8 \\
$\times$ & 37.5 \\
\hline
\end{tabular}

DISCONTINUOUS HEAT SOURCE

\begin{tabular}{|c|c|}
\hline SYMBOL & $\frac{r}{\mathrm{~cm}}$ \\
\hline$\Delta$ & 16 \\
0 & 20 \\
\hline
\end{tabular}

Fia. 9. Correlation for horizontal circular and square heat sources.

with the correlations given in this paper. However, to retain his results in their original form the reverse procedure was adopted; namely, Eq. (12) has in effect been superimposed on Yokoi's results (Fig. 9). The discrepancy in trend between the two sets of data is a result of their different basis. However, the results agree in the region of $z / r$ in the range 2 to 3 corresponding to the heights of the flames for Yokoi's experiments.

Yokoi gives data relating the temperature rise to $s$, the distance along the trajectory of hot gas emerging from windows, when there is no wall above them, a condition Yokoi refers to as "free space." He also gives data relating $s$ to the corresponding vertical height $z$ which is always less than $s$.

In comparing these data with corresponding data on flame height the following approxima- tions and assumptions have been made:

(1) $z \div s$.

(2) In Eq. (18) $m_{w}$ is the total rate of burning while in Yokoi's correlation $H$ is the heat passing through the window. It has been assumed that the difference in origin is partially compensated for by using $L$ from the base of the window in a manner analogous to 8 from the top of the window. The error entailed in this procedure tends to decrease at large values of $L / D$ and $z / r$.

(3) Flame height and temperature depend on $m^{\prime}$ and $H^{\prime}$, respectively, not on $m$ and $H$.

In the region of $z / r$ and $\Theta$, where the results follow the expected relation for a line source, i.e. $\Theta z / r$ is constant, it would be expected from this last assumption that $n^{\frac{1}{}} \Theta z / r$ is constant.

Yokoi's data for different values of $n$ do, in fact, follow this law as is seen in Fig. 10. The equation is

$$
n^{\sharp} \Theta z / r \div 1.0,
$$

where he uses half the window height for $l$.

After substituting for $n$ and $r$ the expression becomes

$$
z=1.0\left(\pi T_{0} / \rho^{2} c^{2} g\right)^{3}\left(H^{\prime 3} / \theta_{c}\right) .
$$

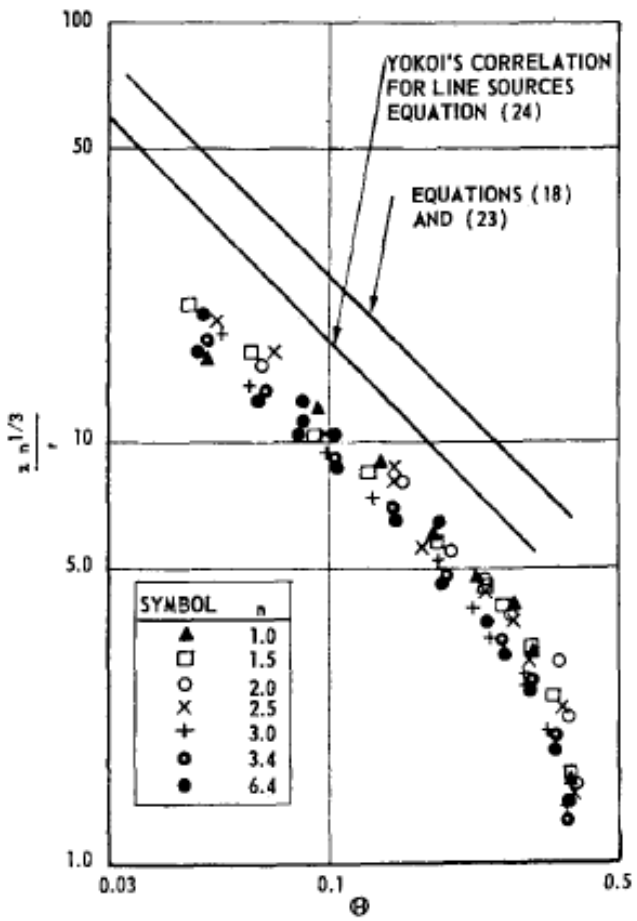

Fig. 10. Yokoi's data replotted as $z n^{1 / 3} / r$ (hot gases from windows). 